\title{
Skin/Subcutaneous Tissue
}

National Cancer Institute

\section{Source}

National Cancer Institute. Skin/Subcutaneous Tissue. NCI Thesaurus. Code C92441.

A tissue sample that contains the epidermis, dermis, and subcutaneous adipose tissue. 